\title{
Non-autoimmune hyperthyroidism caused by thyroid-stimulating hormone receptor germline mutations - 2012 European Thyroid Association Guidelines
}

\author{
R Paschke ${ }^{1}$, M Niedziela $^{2 *}$, B Vaidya $^{3}$, L Persani $^{4}$, B Rapoport $^{5}$, J Leclere ${ }^{6}$ \\ From 4th Congress of the Polish Thyroid Association 2013 \\ Lodz, Poland. 11-13 April 2013
}

\begin{abstract}
All cases of familial thyrotoxicosis with absence of evidence of autoimmunity and all children with persistent isolated neonatal hyperthyroidism should be evaluated for familial non-autoimmune autosomal dominant hyperthyroidism (FNAH) or persistent sporadic non-autoimmune hyperthyroidism (PSNAH). First, all index patients should be analysed for the presence/absence of a thyroid-stimulating hormone (TSH) receptor (TSHR) germline mutation, and if they display a TSHR germline mutation, all other family members including asymptomatic and euthyroid family members should also be analysed. A functional characterization of all new TSHR mutations is necessary. Appropriate ablative therapy is recommended to avoid relapses of hyperthyroidism and its consequences, especially in children. Therefore, in children the diagnosis of FNAH or PSNAH needs to be established as early as possible in the presence of the clinical hallmarks of the disease.
\end{abstract}

\section{Reference}

1. Paschke R, Niedziela M, Vaidya B, Persani L, Rapoport B, Leclere J: 2012 European Thyroid Association Guidelines for the Management of Familial and Persistent Sporadic Non-Autoimmune Hyperthyroidism Caused by Thyroid-Stimulating Hormone Receptor Germline Mutations. In Eur Thyroid J. Volume 1. S. Karger AG, Basel; 2012:142-147, (DOI:10.1159/ 000342982) Copyright (C 2012 European Thyroid Association.

doi:10.1186/1756-6614-6-S2-A45

Cite this article as: Paschke et al:: Non-autoimmune hyperthyroidism caused by thyroid-stimulating hormone receptor germline mutations 2012 European Thyroid Association Guidelines. Thyroid Research 2013 6(Suppl 2):A45.

\begin{abstract}
Author details
${ }^{1}$ Department of Endocrinology and Nephrology, Leipzig University, Leipzig, Germany. ${ }^{2}$ Department of Pediatric Endocrinology and Rheumatology, Poznan University of Medical Sciences, Poznan, Poland. ${ }^{3}$ Department of Endocrinology, Royal Devon and Exeter Hospital, Peninsula Medical School, Exeter, UK. ${ }^{4}$ Department of Clinical Sciences, and Community Health, University of Milan, and Istituto Auxologico Italiano, Milan, Italy. ${ }^{5}$ Autoimmune Disease Unit, Cedars-Sinai Research Institute and School of Medicine, University of California, Los Angeles, CA, USA. ${ }^{6}$ Centre Hospitalier Universitaire de Nancy, Nancy, France.
\end{abstract}

Published: 5 April 2013

2Department of Pediatric Endocrinology and Rheumatology, Poznan University of Medical Sciences, Poznan, Poland

Full list of author information is available at the end of the article
Submit your next manuscript to BioMed Central and take full advantage of:

- Convenient online submission

- Thorough peer review

- No space constraints or color figure charges

- Immediate publication on acceptance

- Inclusion in PubMed, CAS, Scopus and Google Scholar

- Research which is freely available for redistribution 